\title{
PREDSTAVITEV ZNANSTVENEGA, STROKOVNEGA IN PEDAGOŠKEGA DELA PROFESORJA DARKA RADINJE
}

Bogate in vsebinsko sila raznolike, hkrati pa precizne, terminološko dovršene in jezikovno neoporečne znanstvene in strokovne prispevke je profesor Darko Radinja objavljal okroglih pol stoletja, od leta 1950 pa vse do leta 2000. V vzajemnem katalogu COBISS je tako evidentiranih skoraj 300 bibliografskih enot, bolj kot samo število pa je pomembna njihova vsebinska heterogenost, ki kaže na delo in značaj našega profesorja. Seveda se je v posameznih obdobjih svojega raziskovalnega dela izraziteje posvečal določenim problemskim sklopom, kar se odraža tudi v vsebinah objavljenih člankov. Tako ne preseneča, da je zaradi svojih inovativnih pristopov $\mathrm{k}$ različnim problematikam, zaradi svoje večne zagnanosti in preverjanja metodologij, bil utemeljitelj in začetnik novih predmetov in študijskih smeri na Oddelku za geografijo.

Zaradi te njegove specifičnosti smo se odločili, da njegovo dolgoletno delo predstavimo po vsebinskih sklopih in ne po tipologiji dokumentov, ki se uporablja za vodenje bibliografij v vzajemnem katalogu Slovenije. S tem želimo poudariti obseg in heterogenost znanstvenega in strokovnega delovanja profesorja Darka Radinje. Hkrati želimo predstaviti generacijam, ki niso imele priložnosti spoznati in se učiti od profesorja, pristope v geografiji, ki so bili inovativni, podkrepljeni z neprestanim novim iskanjem metodološko boljših rešitev, celotno delo pa je na vseh področjih temeljilo na vztrajnem in dolgoletnem terenskem proučevanju. $\mathrm{V}$ posameznih vsebinskih okvirih so prispevki urejeni kronološko.

Pestrost vsebin predvsem znanstvenih in strokovnih člankov in razprav kaže, da je njihov avtor človek z izjemno strokovno in človeško širino, dodatno pa ga odlikuje velika sistematičnost in vztrajnost pri raziskovanju posameznih znanstvenih problemov.

Znanstvene in strokovne članke in razprave tako predstavljamo $\mathrm{v}$ petih vsebinskih sklopih in sicer:

- geomorfološkem,

- hidrogeografskem,

- varstveno okoljskem,

- didaktičnem in terminološkem ter

- $\quad$ splošnem strokovnem.

Šestdeseta in sedemdeseta leta prejšnjega stoletja so bila zaznamovana predvsem z njegovimi raziskavami in objavami na področju geomorfologije. Tako je leta 1965 izšla tudi doktorska disertacija Morfogeneza Vipavske doline in obrobja, ki predstavlja organsko celoto raziskovanj na območju širšega območja Vipavske doline, ki jo gradi pet samostojnih enot: Morfogeneza Vipavske doline (177 str. in priloge), Nova morfogenetska dognanja na Krasu (133 str. n priloge), Vremska dolina in Divaški kras (80 str. in priloge), Pleistocensko jezero ob spodnji Vipavi (12 str. in priloge) in Morfogenetski položaj spodnjega Goriškega polja (61 str. in priloge). 


\section{Geomorfološki prispevki in razprave}

1. Neka iskustva u proučavanju gruboklastičnog materijala sa morfometrijskom metodom. V: Zbornik VI. kongresa geografov FLRJ v LR Sloveniji od 27. IX. do 5. X. 1961. Ljubljana, Savez geografskih društava FNRJ, Geografsko društvo Slovenije, 1962, str. 235-243.

2. Morfogenetska problematika matičnega Krasa. Geografski obzornik, 13 (1966) št. 3-4, str. 108-114.

3. Medejska gora - najzahodnejši del matičnega Krasa. Geografski obzornik 14 (1967), št. 3, str. 92-94.

4. Morfogenetske poteze Goriškega polja. Geografski vestnik 39 (1967), str. 21-74.

5. Škavnica - kraška mikroreliefna oblika. Geografski obzornik 14 (1967), št. 2, str. 60-63.

6. Vremska dolina in Divaški Kras : problematika kraške morfogeneze. Geografski zbornik 10 (1967), str. 157-269.

7. O obliki in genezi kraškega drobirja. Geografski obzornik 15 (1968), št. 1-2, str. 14-16.

8. O podzemeljski poledenitvi na svetu : zamrznjeni deli litosfere. Geografski obzornik 15 (1968), št. 3-4, str. 28-32.

9. Doberdobski Kras: morfogenetska problematika robne kraške pokrajine $=$ Le karst de Doberdob: problèmes de morphogenèse dans une région karstique marginale. Geografski zbornik 11 (1969), str. 223-279.

10. Renške Dobrave - pokrajinski stik med fluvialno akumulacijo Soče in periglacialno akumulacijo Vipave. Geografski vestnik 41 (1969), str. 61-74.

11. Usad nad Podrago $v$ Vipavski dolini : primer porušenega prirodnega ravnotežja v flišni submediteranski pokrajini $=$ Glissement de terrain en amont de Podraga dans la vallée de la Vipava: exemple d'équilibre détruit dans la région subméditerranéenne de flysch. Geografski zbornik 12 (1971), str. 265-318.

12. Ali so nekdaj po matičnem krasu tekle reke? Proteus 34 (1971/1972), št. 3, str. 109-115.

13. Senožeško podolje: pokrajina na stiku fluvialnega in kraškega reliefa $=$ La vallée de Senožeče: région au contact des reliefs fluvial et karstique. Geografski zbornik 13 (1972), str. 81-126.

14. Zakrasevanje $\mathrm{v}$ Sloveniji v luči celotnega morfogenetskega razvoja $=$ La karsification et l'évolution générale du relief en Slovénie. Geografski zbornik 13 (1972), str. 197-243.

15. Matični Kras: pokrajinska in morfogenetska oznaka. V: Vodnik za ekskurzije. Matični Kras (Vilenica, Škocjanske jame) ; Matarsko podolje (Dimnice) ; Notranjski kras (Postojnski in Cerkniški kras). Postojna, Jamarska zveza Slovenije, 1972, str. 10-18.

16. Caractéristiques fondamentales de la karstification en Slovénie / NW de la Yugoslavie. V: Symposium on karst-morphogenesis. Papers. Szeged, Faculty of Science at Attila József University, 1973, str. 258-270.

17. Prispevek k spoznavanju recentnega abrazijskega reliefa na primeru strunjanske obale. V: Mednarodni mladinski raziskovalni tabori 1971-1972. Ljubljana, Republiški koordinacijski odbor gibanja “Znanost mladini”, 1973, str. 72-94.

18. Prispevek $\mathrm{k}$ prirodnogeografski tipologiji pokrajine $\mathrm{v}$ porečju Voglajne in zgornje Sotle. V: Voglajnsko-sotelska Slovenija. Referati in material na plenarnem delu IX. zborovanja slovenskih geografov v Rogaški Slatini od 5. do 7. oktobra 1973. Ljubljana, 
Geografsko društvo Slovenije, 1974, str. 47-64. (Soavtorji Ivan Gams, Jurij Kunaver, Franc Lovrenčak)

19. Usadi na Sotelskem v pokrajinski luči. V: Voglajnsko-sotelska Slovenija. Referati in material na plenarnem delu IX. zborovanja slovenskih geografov v Rogaški Slatini od 5. do 7. oktobra 1973. Ljubljana, Geografsko društvo Slovenije, 1974, str. 81-95.

20. Matični kras v luči širšega reliefnega razvoja = Le karst proprement dit à la lumière de l'évolution plus large du relief. Acta carsologica 6 (1974), str. 21-33.

21. La corrosion dans les moraines carbonatees au pied des Alpes du sud-est. V: International Geography '76. Section 1, Geomorphology and paleogeography. Moskva, 1976, str. 137141.

22. Osnovne smernice za proučevanje kvartarnih sedimentov in njihove izrabe na Slovenskem. Geografski vestnik 50 (1978), str. 177-190. (Soavtorja: Milan Šifrer, Drago Meze)

23. Usadi v subpanonski Sloveniji. V: Naravne nesreče v Sloveniji kot naša ogroženost. Ljubljana, Slovenska akademija znanosti in umetnosti, 1983, str. 67-74.

24. Kras v luči fosilne fluvialne akumulacije $=$ The karst in the light of fossilized deposition. Acta carsologica 14-15 (1985-1986), str. 99-108

25. Man and karst in the NW part of the Dinaric mountain system - the karst stone walls and enclosures. V: Karst and man. Proceedings of the International symposium on human influence in karst, 11-14th September 1987, Postojna, Yugoslavia. Ljubljana, Department of geography, Philosophical faculty, 1987, str. 111-122.

\section{Hidrogeografski prispevki in razprave}

1. Sava na Ljubljanskem polju. Geografski vestnik 23 (1951), str. 67-84.

2. Porečje - povodje - rečje. Geografski obzornik 2 (1955), št. 4, str. 20-21.

3. Hidroenergetski viri Jugoslavije. Geografski obzornik 5 (1958), št. 1, str. 5-13.

4. Projektirana HE Trnovo v Soški dolini. Geografski obzornik 12 (1965), št. 4, str. 114119.

5. Geografska problematika hidroenergetskega izkoriščanja Soške doline. Geografski obzornik 13 (1966), št. 3-4, str. 98-104.

6. Mednarodno hidrološko desetletje in geografija. Geografski obzornik 16 (1969), št. 2, str. 17-20.

7. Geografsko proučevanje poplavnih področij v Sloveniji. Geografski vestnik 46 (1974), str. 131-146. (Soavtorji: Milan Šifrer, Franc Lovrenčak, Marko Kolbezen, Milan Natek)

8. Geografske značilnosti poplavnega področja ob Pšati = Geographical characteristics of the areas exposed to inundations on the Pšata river system (Central Slovenia) Geografski zbornik 15 (1976), str. 7-160. (Soavtorji: Milan Šifrer, Franc Lovrenčak, Marko Kolbezen, Milan Natek)

9. Največja umetna jezera na svetu - svojevrstna preobrazba pokrajinske sfere. Geografski obzornik 25 (1978), št. 3-4, str. 18-36.

10. Plavajoči mlini v Jugoslaviji: prispevek k regionalni geografiji Panonske nižine. Geografski vestnik 50 (1978), str. 5-15.

11. Rečni režimi v Zgornjem in Srednjem Posočju. V: Zgornje Posočje. Zbornik 10. zbo- 
rovanja slovenskih geografov, Tolmin - Bovec, 26.-28. 9. 1975. Ljubljana, Geografsko društvo Slovenije, 1978, str. 101-125.

12. Geografsko raziskovanje vodnih mlinov in mlinarstva na Slovenskem : osnovne smernice za raziskovanje. Geografski vestnik 51 (1979), str. 121-145.

13. Hidrogeografske raziskave Strunjanskega zaliva. V: Mladinski raziskovalni tabori 19731974. Ljubljana, Republiški koordinacijski odbor gibanja “Znanost mladini”, 1979, str. 96-102.

14. Pomembna, a tudi sporna publikacija našega vodarstva. Geografski vestnik 51 (1979), str. 109-119.

15. Alpine lakes in Yugoslavia. Geographica Iugoslavica 5 (1983), str. 37-46.

16. Sodobna oskrba s pitno vodo v SR Sloveniji in njeno vodovodno omrežje. Geografski vestnik 57 (1985), str. 19-33.

17. Oskrba s pitno vodo v novomeški občini. V: Dolenjska in Bela krajina. Prispevki za 13. zborovanje slovenskih geografov v Dolenjskih Toplicah od 12.-14. oktobra 1984. Ljubljana, Geografsko društvo Slovenije, 1984, str. 111-128.

18. Mlinarska in žagarska raba tekočih voda v Zgornjem Pomežju ter možnosti za njihovo ponovno rabo s pomočjo malih hidroelektrarn (MHE). V: Geografsko proučevanje primernosti organiziranja proizvodnih celic na Koroškem. Raziskovalna naloga. Ljubljana, Znanstveni institut Filozofske fakultet, 1985, str. 235-270.

19. Naravne in tehnično-ekonomske osnove za male HE v zgornji Mežiški dolini. V: Geografsko proučevanje uvajanja celične proizvodnje na Koroškem. Ljubljana, Oddelek za geografijo, Znanstveni inštitut Filozofske fakultete, 1986, str. 67-84. (Dela ; 2) (Soavtorja: Dušan Plut, Marcel Kompare)

20. Tradicionalne oblike vodne oskrbe na Notranjskem: v občinah Cerknica, Postojna, Ilirska Bistrica. V: Notranjska. Zbornik 14. zborovanja slovenskih geografov, Postojna, 15.17. oktobra 1987. Ljubljana, Zveza geografskih društev Slovenije, 1987, str. 145-154.

21. Porečje - povodje - vodozbirno območje in podobno. Ujma 1991, št. 5, str. 270-271.

22. Hidrogeografske značilnosti Posavinja in njegova oskrba s pitno vodo: aktualna pokrajinska problematika. V: Savinjska, možnosti regionalnega in prostorskega razvoja. 16. zborovanje slovenskih geografov, Celje, 21.-23. oktobra 1993. Ljubljana, Zveza geografskih društev Slovenije, 1993, str. 55-89. (Soavtorica: Elizabeta Zoretič)

\section{Varstveno okoljski prispevki in razprave}

1. Načrti o zaščiti kraške pokrajine na Tržaškem. Geografski obzornik 14 (1967), št. 4, str. 117-121.

2. Onesnaženost človekovega okolja v luči geografske terminologije. Geografski obzornik 19 (1972), št. 1, str. 35-39.

3. Geografija in varstvo človekovega okolja: (pogledi na geografijo v luči varstva človekovega okolja). Geografski vestnik 46 (1974), str. 110-120.

4. Onesnaževanje pokrajin in pokrajinske sfere z nafto. Geografski obzornik 24 (1977), št. $1-2$, str. 30-40.

5. Onesnaženost slovenskih rek in njene pokrajinske značilnosti: prispevek k regionalni geografiji Slovenije. Geografski vestnik 51 (1979), str. 3-18. 
6. Pokrajinske razsežnosti in značilnosti industrializacijske onesnaženosti v Sloveniji. V: Geografski problemi življenjskega okolja. Ljubljana, Inštitut za geografijo univerze v Ljubljani, 1979, str. 75-83. (Geographica Slovenica ; 9)

7. Onesnaževanje in varstvo okolja na primeru izbranega industrijskega ali kmetijskega obrata (zadruge): navodila za raziskavo. Geografski obzornik 27 (1980), št. 3-4, str. 4447.

8. Degradacija okolja v Radovljiški kotlini. V: Usmerjanje regionalnega razvoja Slovenije. Slovenske Alpe, severovzhodna Slovenija, Bela krajina. Ljubljana, Inštitut za geografijo Univerze Edvarda Kardelja, 1983, str. 64-66. (Geographica Slovenica ; 14)

9. Degradacija vode v Radovljiški kotlini. V: Usmerjanje regionalnega razvoja Slovenije. Slovenske Alpe, severovzhodna Slovenija, Bela krajina. Ljubljana, Inštitut za geografijo Univerze Edvarda Kardelja, 1983, str. 66-72. (Geographica Slovenica ; 14)

10. Snežna odeja v SR Sloveniji sredi decembra 1986 ter vprašanje onesnaženosti našega okolja. Geografski vestnik 59 (1987), str. 21-35.

11. Vprašalnik o degradaciji okolja: primer za anketiranje podeželjskih naselij trboveljske občine. V: Za ekološko svetlejši jutri. Ljubljana, Zveza organizacij za tehnično kulturo Slovenije, 1985, str. 108-115. (Soavtorja Dušan Plut, Metka Špes)

12. Onesnaženost okolja v Sloveniji (posebej na Notranjskem), ugotovljena na podlagi snežne odeje sredi decembra 1986. V: Notranjska. Zbornik 14. zborovanja slovenskih geografov, Postojna, 15.-17. oktobra 1987. Ljubljana, Zveza geografskih društev Slovenije, 1987, str. 411-420.

13. Varstvo okolja in geografija. V: Notranjska. Zbornik 14. zborovanja slovenskih geografov, Postojna, 15.-17. oktobra 1987. Ljubljana, Zveza geografskih društev Slovenije, 1987, str. 19-22.

14. O tehnogenem kroženju žvepla v pokrajinskem okolju SR Slovenije in njegovi bilanci : prispevek k vprašanju zakisanosti naših padavin in okolja sploh. Geografski vestnik 60 (1988), str. 3-19.

15. Širša degradacijska problematika Blejskega jezera: (z vidika njegove pokrajinske strukture). V: Pokrajinski učinki človekovih dejavnosti na življenjsko okolje. Jugoslovansko posvetovanje z mednarodno udeležbo, Bled 21. do 24 sept. 1987. Ljubljana, Inštitut za geografijo Univerze Edvarda Kardelja, 1988, str. 99-134. (Geographica Slovenica ; 19)

16. Širjenje onesnaženega zraka v mestu ali industrijskem kraju : proučevanje lokalne zračne cirkulacije s pomočjo dima iz tovarniških in drugih dimnikov. Geografski obzornik 36 (1989), št. 3-4, str. 36-40.

17. Obremenjevanje pokrajinskega okolja v Sloveniji zaradi energijske intenzivnosti "družbenega" kmetijstva. Geografski vestnik 68 (1996), str. 103-121.

18. Kmetijsko obremenjevanje okolja v Spodnjem Podravju s Prlekijo v energijski in nitratni osvetlitvi. V: Spodnje Podravje s Prlekijo : možnosti regionalnega in prostorskega razvoja. 17. zborovanje slovenskih geografov, Ptuj, 23.-26. oktober 1996. Ljubljana, Zveza geografskih društev Slovenije, 1996, str. 153-164.

19. Vprašanja o agrarnem preobremenjevanju pokrajinskega okolja v Sloveniji. Geografija v šoli 6 (1997), št. 2-3, str. 105-109. 
20. Kmetijsko obremenjevanje slovenskega alpskega sveta na izbranem primeru. V: Socialnogeografski problemi. Posvečeno 70. letnici prof. Vladimirja Klemenčiča. Ljubljana, Oddelek za geografijo Filozofske fakultete, 1997, str. 229-263. (Dela ; 12)

21. Problematika sonaravnega razvoja v slovenskem alpskem svetu (na primeru Rateške pokrajine). V: Sonaravni razvoj v slovenskih Alpah in sosedstvu. Ljubljana, Oddelek za geografijo, Znanstveni inštitut Filozofske fakultete, 1999, str. 115-133. (Dela ; 13)

\section{Didaktični in terminološki prispevki ter razprave}

1. Nekaj misli o geografiji v šoli. Geografski obzornik 1 (1954), št. 1, str. 3-4.

2. Nekaj misli o vzrokih sedanjega položaja geografije v srednji šoli. Geografski obzornik 2 (1954), št. 2, str. 4-7.

3. Geografija - fakultativni maturitetni predmet. Geografski obzornik 2 (1955), št. 4, str. 14-17.

4. Zemljepisno imenoslovje. Geografski obzornik 2 (1955), št. 4, str. 21-22.

5. Zemljepisno izrazje. Geografski obzornik 2 (1955), št. 4, str. 17-18.

6. Antropogeografija - kulturna geografija - družbena geografija v terminološki luči. Geografski obzornik 5 (1958), št. 3, str. 29-30.

7. Geografsko izrazje in imenoslovje. Geografski obzornik 5 (1958), št. 4, str. 17-18.

8. Nove pobude za pouk geografije v gimnaziji. Geografski obzornik 5 (1958), št. 3, str. 23-28.

9. Fizična geografija - prirodna geografija v terminološki luči. Geografski obzornik 6 (1959), št. 1-2, str. 19-20.

10. Iz problematike nastave geografije u gimnaziji. V: Zbornik radova. V. kongres geografa FNR Jugoslavije održanog u NR Crnoj Gori od 8.-16. septembra 1958. Cetinje, Geografsko društvo NR Crne Gore, 1959, str. 365-371.

11. Nekaj izrazov hidrogeografske terminologije. Geografski obzornik 6 (1959), št. 3, str. 52-54.

12. Za implicitno geografijo. Geografski obzornik 6 (1959), št. 1-2, str. 17-18.

13. Zemljepisna lega - zemljepisni položaj. Geografski obzornik 6 (1959), št. 4, str. 67-68.

14. Geografski diafilm in diapozitiv v didaktično-metodični luči ter njuna medsebojna problematika. Geografski obzornik 7 (1960), št. 3, str. 66-74.

15. Reformirani študij geografije na univerzi. Geografski obzornik 9 (1962), št. 3-4, str. 3943.

16. Problematika o izhodišču univerzitetnega študija geografije na prvi stopnji. Geografski obzornik 9 (1962), št. 3-4, str. 30-36; 10 (1963), št. 1-2, str. 10-18; 10 (1963), št. 3-4, str. 58-64.

17. Nekaj problemov geomorfološke terminologije. Geografski obzornik 11 (1964), št. 1, str. 19-21.

18. Osnovne koncepcije geografskega študija. Geografski obzornik 11 (1964), št. 1, str. 1315.

19. O sistemu univerzitetnega študija geografije v Sovjetski zvezi. Geografski obzornik 16 (1969), št. 1, str. 14-19. 
20. Planetologija in geografija. Geografski obzornik 16 (1969), št. 1, str. 25.

21. O kompleksnosti v geografiji in izven nje. Geografski vestnik 49 (1977), str. 25-30.

22. Prostor - pokrajinski prostor - pokrajina. Geografski obzornik 24 (1977), št. 1-2, str. 53-56.

23. Vpogled v jugoslovansko geografijo. Geografski obzornik 26 (1979), št. 1-2, str. 12-26.

24. Geografija in usmerjeno izobraževanje. Geografski obzornik 27 (1980), št. 1-2, str. 1225.

25. Razprava o geografiji. Geografski vestnik 53 (1981), str. 90-92.

26. O terminološki problematiki v slovenski geografiji : na izbranih primerih. V: Geografija in aktualna vprašanja prostorskega razvoja. 70 let geografije na ljubljanski univerzi. Ljubljana, Oddelek za geografijo Filozofske fakultete, Znanstveni inštitut , 1989, str. 185 195. (Dela ; 6)

\section{Splošno strokovni prispevki in razprave}

1. Industrija nafte v Romuniji. Geografski obzornik 2 (1955), št. 4, str. 10-12.

2. Malarija v svetu: nekaj geografskih aspektov. Geografski obzornik 2 (1955), št. 3, str. 3-6.

3. Politična geografija in geopolitika. Geografski obzornik 3 (1956), št. 4, str. 65-70.

4. Izkoriščanje sončne energije. Geografski obzornik 4 (1957), št. 1, str. 12-14.

5. Energetski viri Jugoslavije. Geografski obzornik 5 (1958), št. 4, str. 9-15.

6. Gospodarsko izkoriščanje nuklearne energije v svetu. Geografski obzornik 5 (1958), št. 3, str. 13-19.

7. Plovne reke in kanali. Potniški promet. Geografski obzornik 5 (1958), št. 4, str. 20-21.

8. Premogovno bogastvo Jugoslavije. Geografski obzornik 5 (1958), št. 2, str. 5-8.

9. Nekaj misli s posveta o prirodni geografiji. Geografski obzornik 13 (1966), št. 1, str. 25 29.

10. Ali obstaja Zalivski tok? Geografski obzornik 16 (1969), št. 3-4, str. 30-31.

11. Nova spoznanja o obliki Zemlje v geografski luči. Geografski obzornik 16 (1969), št. 3-4, str. 22-25.

12. Zanimiv hidrološki pojav v Rdečem morju. Geografski obzornik 16 (1969), št. 1, str. 2425.

13. Beseda ob odkritju doprsnega kipa akademika Antona Melika na Filozofski fakulteti ob 10. obletnici njegove smrti 15. VI. 1976. Geografski obzornik 23 (1976), št. 3-4, str. 1-3.

14. Značilnosti vodne oskrbe v naftnih pokrajinah puščavskega sveta, razsoljevanje morske vode v današnjem svetu. Geografski obzornik 27 (1980), št. 3-4, str. 9-16.

15. Ob smrti dr. Vladimirja Kokoleta (25. 6. 1925 - 11. 5. 1993). Geografski vestnik 65 (1993), str. 159-161.

16. Prof. dr. Ivan Gams 75-letnik. Delo 40 (15.jul. 1998), št. 161, str. 12.

17. Prirodnogeografsko proučevanje strunjanske doline. V: Mladinski raziskovalni tabori 1973-1974. Ljubljana, Republiški koordinacijski odbor gibanja “Znanost mladini”, 1979, str. 55-68.

18. Naravne nesreče v geografski luči. V: Prirodne nepogode u Jugoslaviji sa posebnim osvrtom na metodologiju geografskog proučavanja. Zbornik saveznog simpozija o me- 
todologiji geografskog proučavanja prirodnih nepogoda, Ljubljana, 13.-15. 10. 1983. Ljubljana, Filozofska fakulteta, Oddelek za geografijo, 1983, str. 17-29.

19. Žledne ujme v Sloveniji. V: Naravne nesreče v Sloveniji kot naša ogroženost. Ljubljana, Slovenska akademija znanosti in umetnosti, 1983, str. 107-115.

20. Modern agricultural land improvement in Slovene Dinaric karst. V: Karst and man. Proceedings of the International Symposium on human influence in karst, 11-14th September 1987, Postojna, Yugoslavia. Ljubljana, Department of Geography, Philosophical Faculty, 1987, str. 123-135.

21. Častitljiv, vendar nesklenjen razvoj fizičnogeografskega laboratorija. Praznujemo njegovo sedemdesetletnico ali dvaindvajsetletnico?. V: Geografija in aktualna vprašanja prostorskega razvoja. 70 let geografije na ljubljanski univerzi. Ljubljana, Oddelek za geografijo Filozofske fakultete, Znanstveni inštitut, 1989, str. 198-302. (Dela ; 6)

22. Sedemdeset let fizične geografije na ljubljanski univerzi. V: Geografija in aktualna vprašanja prostorskega razvoja. 70 let geografije na ljubljanski univerzi. Ljubljana, Oddelek za geografijo Filozofske fakultete, Znanstveni inštitut, 1989, str. 9-21. (Dela ; 6)

23. Dimenzije Tržaškega zaliva in slovenskega morja ter njihov regionalni pomen. V: Primorje. Zbornik 15. zborovanja slovenskih geografov, Portorož, 24. - 27. oktobra 1990. Ljubljana, Zveza geografskih društev Slovenije, 1990, str. 13-20.

24. Pokrajinske značilnosti Tržaškega zaliva in Koprskega Primorja : pomorske in obmorske poteze obeh pokrajin na sedanji stopnji antropogene preobrazbe. V: Primorje. Zbornik 15. zborovanja slovenskih geografov, Portorož, 24. - 27. oktobra 1990. Ljubljana, Zveza geografskih društev Slovenije, 1990, str. 7-12.

25. Polhograjsko hribovje. V: Regionalnogeografska monografija Slovenije. 2. del. Zahodni predalpski svet. Ljubljana, Znanstvenoraziskovalni center SAZU, Geografski inštitut, 1996, str.. 55-68.

26. Predgovor. V: Šaleška jezera : vpliv premogovništva na pokrajinsko preobrazbo Šaleške doline. Velenje, Erico, 1999, str. 6.

Med splošnimi strokovnimi članki se je že v 50-ih letih loteval povsem novih vsebin kot npr. izkoriščanje sončne energije ali gospodarsko izkoriščanje nuklearne energije v svetu. Vseskozi se je ukvarjal tako s terminološkim kot vsebinskim področjem geografije in njenega delovanja.

Podal je metodološke in teoretske smernice za raziskovanje na številnih področjih; Osnovne smernice za proučevanje kvartarnih sedimentov in njihove izrabe na Slovenskem (1978), Geografsko raziskovanje vodnih mlinov in mlinarstva na Slovenskem (1979), Onesnaževanje in varstvo okolja na primeru izbranega industrijskega ali kmetijskega obrata (navodila za raziskavo (1980)), Vprašalnik o degradaciji okolja: primer za anketiranje podeželskih naselij trboveljske občine (1985), Naravne in tehnično-ekonomske osnove za male HE v zgornji Mežiški dolini (1986), Kmetijsko obremenjevanje okolja (1993).

Poleg objavljenih prispevkov je dr. Radinja pripravil še številne tipkopisi, ki niso bili nikoli objavljeni, večkrat skrbno dopolnjeni, najpogosteje pa so služili kot dodatno delovno gradivo študentom dodiplomskega in predvsem podiplomskega študija. 
Poleg navedenih znanstvenih in strokovnih prispevkov, ki predstavljajo osrednje raziskovalno področje dr. Radinje, je sodeloval tudi pri pripravi enciklopedij in leksikonov. Tako je prispeval gesla že za Enciklopedijo Jugoslavije in kasneje tudi Enciklopedijo Slovenije ter sodeloval pri Geografskem terminološkem slovarju.

Omeniti velja še 49 recenzij oziroma kritik različnih znanstvenih in strokovnih geografskih in negeografskih del. Pomemben je tudi profesorjev prispevek pri pripravi vrste srednješolskih učbenikov ter drugega učnega gradiva, kjer je kot soavtor sodeloval od leta 1980 do 1995.

Profesor Radinja je med geografi različnih generacij še danes predvsem cenjen in poznan po svojem pedagoškem, mentorskem delu. Ne le kot mentor doktorandom, ampak tudi kot mentor pri magistrskih in diplomskih delih. Celo pri izdelavi seminarskih nalog, ki so bile pogosto tematske in usmerjene $\mathrm{v}$ problematike, katerih se je sam raziskovalno loteval, je svoje delo profesorja in mentorja opravljal vztrajno, natančno, visoke kriterije pri izdelavi nalog je imel tako pri vsebinski in metodološki kot tudi jezikovni zgradbi.

Od leta 1980 dalje je bil mentor sedmim doktorandom, desetim magistrom in oseminštiridesetim diplomantom ter številnim seminarskim in drugim samostojnim raziskovalnim nalogam. Profesor pa ostaja mentor tako na strokovnem kot življenjskem področju številnim generacijam svojih učencev tudi zadnja leta, ko ga imamo priložnost poslušati in na njemu lasten izzivalen način razpravljati tako v zvezi z različnimi strokovno-raziskovalnimi vsebinami kot tudi najrazličnejšimi poljudnimi temami.

\section{Mentor pri doktorskih disertacijah}

1. PLUT, Dušan. Vode v Beli krajini in njihova uporaba: hidrogeografska raziskava Bele krajine. Ljubljana, 1984.

2. SMIRČIĆ, Ante. Površinski valovi otvorenog Jadrana uzrokovani vjetrom u vidu prirodno geografskih svojstava. Ljubljana, 1985.

3. VUČAK, Zoran. Strujanje u sjevernom Jadranu u vidu uzroka i posljedica. Ljubljana, 1985.

4. KRANJC, Andrej. Recentni fluvialni jamski sedimenti, njihovo nastajanje in vloga v speleogenezi. Ljubljana, 1986.

5. ŠPES, Metka. Degradacija okolja kot dejavnik diferenciacije urbane pokrajine (na izbranih slovenskih primerih). Ljubljana, 1994.

6. REJEC BRANCELJ, Irena. Agrarnogeografske značilnosti slovenskih pokrajin z vidika varstva okolja. Ljubljana, 1999.

7. LAMPIČ, Barbara. Agrarno obremenjevanje okolja na Slovenskem v energetski osvetlitvi: na izbranih primerih. Ljubljana, 2002. (Somentor)

\section{Mentor pri magistrskih delih}

1. OROŽEN ADAMIČ, Milan. Geografski učinki potresov v letu 1976 v Sloveniji. Ljubljana, 1979.

2. BRINOVEC, Slavko. Avdiovizualna sredstva pri pouku geografije s posebnim ozirom na grafoskop. Kranj, 1980. (Somentor)

3. ŠPES, Metka. Pokrajinski učinki onesnaževanja okolja v Celju in okolici. Ljubljana, 1985. 
4. STEPANČIČ, Vojka. Poznavanje geografskih pojmov na stopnji razrednega pouka : na primeru petih šol na Goriškem. Šempeter pri Gorici, 1987.

5. BRICELJ, Mitja. Gospodarska izraba Save in varstvo njenega okolja. Ljubljana, 1990.

6. REJEC BRANCELJ, Irena. Agrarnogeografska problematika Koprskega primorja z vidika varstva okolja. Ljubljana, 1993.

7. ROJŠEK, Daniel. Geografsko vrednotenje naravne dediščine na primeru Škocjanskega jamskega spleta z okolico in varstvo okolja. Ljubljana, 1994.

8. BOGATAJ, Nevenka. Degradacija gozda s posebnim ozirom na metodološko problematiko popisa. Ljubljana, 1997.

9. ŠTERBENK, Emil. Premogovniške ugreznine in ojezeritve v Šaleški dolini ter varstvo okolja. Velenje, 1998.

10. SMREKAR, Aleš. Varstvo kraškega okolja na primeru Cerkniškega jezera. Ljubljana, 2000.

\section{Mentor pri diplomskih delih}

1. VIDEC, Rok. Geografsko raziskovanje vodnih mlinov in mlinarstva v porečju Hudinje. Ljubljana, 1980.

2. KLEMENC, Branka. Morski tokovi v Jadranu. Ljubljana, 1980.

3. GRLICA, Franc. Oskrba z vodo v okolici Stične. Šentvid pri Stični, 1980.

4. BELTRAM, Gordana. Geografske značilnosti Severnega Jadrana. Ljubljana, 1981.

5. SIMIĆ, Marko. Krnsko jezero. Ljubljana, 1981.

6. ŠTROZAK, Janja. Oskrba z vodo v Grosupeljski kotlini. Grosuplje, 1981.

7. STANJKO, Zdenka. Degradacija pokrajinskih elementov v Sloveniji in tipološki oris. Ljubljana, 1982.

8. GREGORČIČ, Maja. Didaktičnometodična analiza učbenika in delovnega zvezka geografije za skupno vzgojnoizobraževalno osnovo srednjega izobraževanja, Mladinska knjiga, Ljubljana 1981. Ljubljana, 1982.

9. PUC, Matjaž. Varstvo matičnega Krasa v obliki naravnega parka. Ljubljana, 1982.

10. BRICELJ, Mitja. Degradacija okolja na primeru Industrije usnja Vrhnika. Ljubljana, 1983.

11. STANKOVIČ, Milivoj. Mežiška dolina v luči degradacije okolja. Ljubljana, 1983.

12. GABRENJA, Branka. Oskrba z vodo na Knežji njivi, na Vrhu in v Markovcu. Ljubljana, 1983.

13. DOVER, Andreja. Varstvo okolja v občini Ljubljana-Šiška : s posebnim ozirom na zazidavo tal. Ljubljana, 1983.

14. FURLAN, Karmen. Luka Koper. Ljubljana, 1984.

15. KNEZ, Ida. Triglavski narodni park. Ljubljana, 1984.

16. DOLGAN, Mojca. Degradacijski učinki gozdnih požarov v Slovenskem Primorju. Ljubljana, 1986.

17. ŠAJN, Jadranka. Pokrajinska problematika Sečoveljskih solin. Ljubljana, 1986.

18. KUKANJA, Teja. Melioracije v Vipavski dolini z vidika varstva okolja. Ljubljana, 1987.

19. REJEC, Irena. Vpliv pojezerja na onesnaženost Blejskega jezera. Ljubljana, 1987. 
20. GREGORIČ, Anica. Degradacija okolja v Anhovem. Ljubljana, 1988.

21. JANKOVIČ, Janja. Regionalna problematika odlaganja smeti na Ljubljanskem barju, posebej na centralni deponiji. Ljubljana, 1988.

22. ŠIPEC, Slavko. Jesenice in njihova ekološko - geografska problematika. Ljubljana, 1990.

23. REMIH, Ingrid. Predvidena HE Boštanj na Savi in njen vpliv na okolje. Ljubljana, 1990.

24. CIGALE, Dejan. Degradacija in varstvo okolja na primeru prašičerejske farme v Ihanu na Bistriški ravnini. Ljubljana, 1991.

25. HRVATIN, Mauro. Geografska problematika varovanja kraških vodnih virov : na primeru hidrografskega zaledja kraških izvirov v Malnih pri Planini. Ljubljana, 1991.

26. BREČKO, Valentina. Izbrana kmetijska posestva na Ljubljanskem barju z vidika varstva okolja. Ljubljana, 1991.

27. TOMAŽIČ, Mojca. Onesnaženost ozračja v Celju. Ljubljana, 1991.

28. LIPOVŠEK, Nataša. Skaruško polje sredi Ljubljanske kotline s poudarkom na vodni oskrbi. Ljubljana, 1991.

29. PAVŠEK, Miha. Lokacijska problematika pretakališča in skladišča kemikalij z vidika varstva okolja: opredelitev strokovne podlage za možno lokacijo pretakališča in skladišča topil, kislin in lugov v Ljubljani. Ljubljana, 1992.

30. ZORETIČ, Elizabeta. Nov pogled na življenje na Zemlji, tudi z geografskega zornega kota. Ljubljana, 1992.

31. FRAJZMAN, Polona. Degradacijska in okoljevarstvena problematika Mežiške doline. Ravne na Koroškem, 1993.

32. TOMAŠIČ, Niran. Geografske značilnosti komunalnih in industrijskih odlagališč odpadkov v Celju. Celje, 1993.

33. DRNOVŠEK, Stanka. Okoljevarstvena problematika HE Mavčiče na Kranjsko-Sorškem polju. Ljubljana, 1993.

34. ODAR, Špela. Okoljevarstvena problematika izravnavanja grbinastih travnikov v Bohinju. Bohinj, 1993.

35. NAPOKOJ, Matjaž. Okoljevarstvena problematika odlagališč komunalnih in posebnih odpadkov v kranjski občini. Kranj, 1993.

36. HABIČ, Andreja. Antropogene spremembe v današnjem svetu: (problematika varstva okolja). Ljubljana, 1994.

37. RADEŽ, Mateja. Geografska problematika predvidene male hidroelektrarne Krajcarica v Triglavskem narodnem parku z vidika varstva okolja. Kamnik, 1994.

38. ŠOLAR, Helena. Problematika varstva okolja v Radovni. Ljubljana, 1994.

39. ŠPILAR, Špela. Socialno-ekološka problematika Trboveljske doline: njena degradacija in odnos prebivalstva do nje. Trbovlje, 1994.

40. LAMPIČ, Barbara. Kmetijsko obremenjevanje okolja na Kranjskem polju v energetski luči: na primeru naselja in katastrske občine Spodnji Brnik. Ljubljana, 1995.

41. SMREKAR, Aleš. Okoljevarstvena problematika agrarne rabe tal na Ljubljanskem barju v energetski osvetlitvi na primeru Črne vasi in Lip. Ljubljana, 1995. 
42. JAKIČ, Maja. Okoljevarstvena problematika sedanjih gramoznic na Ljubljanskem polju. Ljubljana, 1995.

43. JARNJAK, Marjan. Okoljevarstvena problematika Škocjanskega zatoka pri Kopru. Ljubljana, 1995.

44. SITAR, Marjana. Agrarno obremenjevanje okolja v Deželi v energijski luči : na primeru Poljč, Hraš in farme v Poljčah. Radovljica, 1996.

45. URBANC, Mimi. Kmetijsko obremenjevanje okolja na Gorenjskih Dobravah v energetski luči: na primeru naselij Goriče, Letence in Srednja vas. Ljubljana, 1996.

46. KOSI, Danilo. Regionalni oris Dravskega Kozjaka. Ljubljana, 1996.

47. ŠTRAVS, Elizabeta. Regionalna geografija srednje in spodnje Poljanske doline. Ljubljana, 1997.

48. ŽELJEZNOV, Maruška. Geografija Polhovega Gradca. Ljubljana, 1999.

Ida Knez Račič

Dr. Barbara Lampič 